\title{
PERANCANGAN APLIKASI PENGANTARAN BARANG (EKSPEDISI) ANTAR SUMATERA BERBASIS ANDROID
}

\author{
*Nina Veronika Tarigan, Calvin, Delima Sitanggang, Evta Indra \\ Program Studi Sistem Informasi \\ Fakultas Teknologi dan Ilmu Komputer Universitas Prima Indonesia \\ E-mail : *ninaveronikatarigan@gmail.com
}

\begin{abstract}
ABSTRAK- Kegiatan pengantaran barang merupakan kegiatan yang sangat sering dilakukan oleh masyarakat, baik masyarakat umum maupun perusahaan. Barang yang diantar berbagai jenis, mulai dari barang kecil, hingga besar. Di pulau sumatera ada banyak perusahaan pengangkutan yang setiap hari beroperasi, mulai dari dalam kota hingga ke luar kota. Sangat banyak masyarakat dan perusahaan yang membutuhkan jasa pengantaran barang. Namun selama ini belum ada sistem atau aplikasi yang membantu memberi kemudahan bagi masyarakat untuk pemesanan angkutan pengantaran barang, sehingga kurang maksimalnya pelayanan jasa dalam pengantaran barang. Pada penelitian ini penulis merancang aplikasi pengantaran barang berbasis android. Sehingga masyarakat ataupun perusahaan dapat memesan pengangkutan dengan menggunakan smartphone yang memiliki sistem operasi android yang dapat digunakan kapan saja dan dimana saja. Aplikasi dirancang menggunakan bahasa pemrograman Java dan menggunakan Android Studio. Dengan adanya perancangan aplikasi ini nantinya akan mempermudah proses pemesanan, pengamanan, dan pelayanan pengantaran barang (ekspedisi).
\end{abstract}

Kata kunci : Pengantaran barang, Pengangkutan, Sistem, Android.

\section{PENDAHULUAN}

Penggunaan telepon genggang sangat luas di berbagai kalangan khususnya telepon genggam yang menggunakan sistem operasi android yang sangat populer digunakan saat ini. Dengan memanfaatkan android, banyak yang membuat dan mengembangkan sistem tersebut dalam bisnis pengangkutan barang atau yang sering disebut dengan ekspedisi. Perusahaan transportasi salah satu perusahaan yang sangat dikenal dan dibutuhkan oleh masyarakat luas dan juga perusahaan, yakni dalam kegiatan pengiriman barang dari kawasan perkotaan hingga pedesaan.

Setiap perusahaan pengantaran barang yang sedang berkembang ataupun sudah maju pasti sangat membutuhkan sistem informasi yang dapat memproses pengelolaan data pada perusahaan tersebut, yang keseluruhan aktifitas kegiatan transaksi dapat dilakukan menggunakan. Pada penelitian sebelumnya dengan menggunakan aplikasi penjemputan dalam mengambil paket toko online berbasis Andoroid sehingga penghematan waktu penjemputan paket lebih efisien[1].

Oleh karena itu kebutuhan akan sistem dan kemampuan manajemen saat ini sangatlah mendesak untuk kemajuan perusahaan. Untuk itu perlu dilakukan perancangan sistem informasi jasa pengiriman barang yang pemesanannya dapat dilakukan menggunakan smartphone saja. Sehingga dapat mengakomodir kebutuhan akan permintaan jasa pengiriman barang yang semakin meningkat setiap waktunya.

Dari permasalahan yang telah dijelaskan sebelumnya, maka penelitian ini berfokus pada pemecahan masalah, merancang sistem baru untuk pemesanan, pengiriman serta pengelolaan data transaksi dengan mudah dan dapat memberi manfaat, baik bagi perusahaan maupun masyarakat luas. Jika selama ini masyarakat harus menghubungi ekspedisi dalam hal pengantaran barang, pindah rumah, baik dalam kota maupun keluar kota. Aplikasi dirancang menggunakan bahasa pemrograman java, dengan memanfaatkan IDE Android Studio.

Proses pemesanan angkutan dapat dilakukan dimana saja dan kapan saja dengan menggunakan smartphone. Keuntungan yang diperoleh perusahaan yaitu perusahaan akan semakin dikenal, dan semakin banyak mendapat pelanggan, selain itu, kemudahan kerja juga dapat dimudahkan, seperti pengecekan data perjalanan, laporan keuangan baik pemasukan dan pengeluaran, dan juga perusahaan akan mendapat respon kebutuhan dari pelanggan secara langsung karena dari aplikasi disediakan nomor telepon dari perusahaan jasa pengangkutan tersebut.

\section{ISI PENELITIAN}

\subsection{Landasan Teori}

\section{A. Ekspedisi}

Ekspedisi (pengangkutan) dapat diartikan sebagai proses kegiatan transportasi memindahkan barang atau penumpang dari satu tempat ke tempat lain, atau dengan kata lain pengangkutan (ekspedisi) sama dengan jasa bagi masyarakat yang membutuhkan dan sangat bermanfaat untuk pemindahan atau pengiriman barang ke tempat lain.

\section{B. Barang}

Barang dapat diartikan sebagai produk fisik yang terlihat atau berwujud, yang dapat diberikan, digunakan dan menjadi hak milik serta dapat dipindahtangankan dari satu orang ke orang lain.

\section{Sistem Informasi}


Sistem informasi yaitu kumpulan data yang diolah menjadi bentuk yang lebih berguna dan bermanfaat. Tanpa adanya informasi, suatu sistem tidak akan dapat berjalan atau bahkan dapat terhenti.

\section{Android}

Android yaitu sebuah sistem operasi untuk perangkat mobile berbasis linux yang mencakup sistem operasi dan aplikasi. Android menyediaan platform terbuka bagi para pengembangan untuk menciptakan aplikasi.

\section{E. Java}

Java merupakan perangkat lunak yang multipurpose, multiplatform, dan sangat mudah dipelajari yang dapat membuat seluruh bentuk aplikasi tidak hanya desktop dan web, namun dapat juga membuar aplikasi mobile sebagaimana dibuat dengan menggunakan bahasa pemrograman konvensional lainnya.

\subsection{Metodologi Penelitian}

Metode penelitian yang ingin dirancang tersebut pertama yang dilakukan adalah Pengumpulan data berdasarkan kebutuhan sistem dari perusahaan yang diteliti dengan melakukan wawancara pada perusahaan. Berikutnya Analisis sistem yaitu menganalisis sistem yang sedang berjalan pada perusahaan tersebut. Perancangan sistem dengan menggunakan use case diagram dan membuat class diagram serta perancangan terhadap skema database. Selanjutnya sistem akan di uji atau melakukan testing pada aplikasi untuk mengetahui kelayakan dari sistem. Gambaran umum metodologi penelitian ini, dapat dilihat dari gambar 1 berikut:

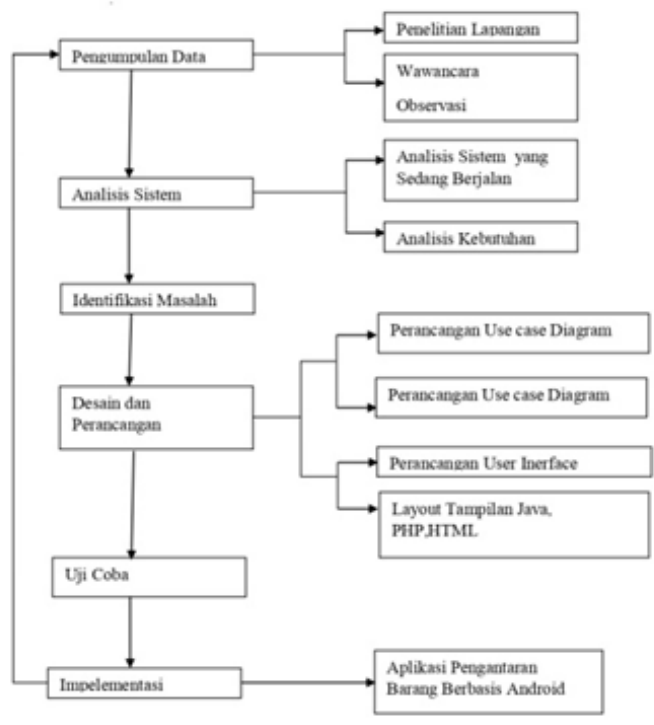

Gambar 1. Metodelogi Penelitian

\subsection{Gambaran Umum Sistem}

Gambaran umum Sistem dapat dilihat pada gambar 2 berikut:

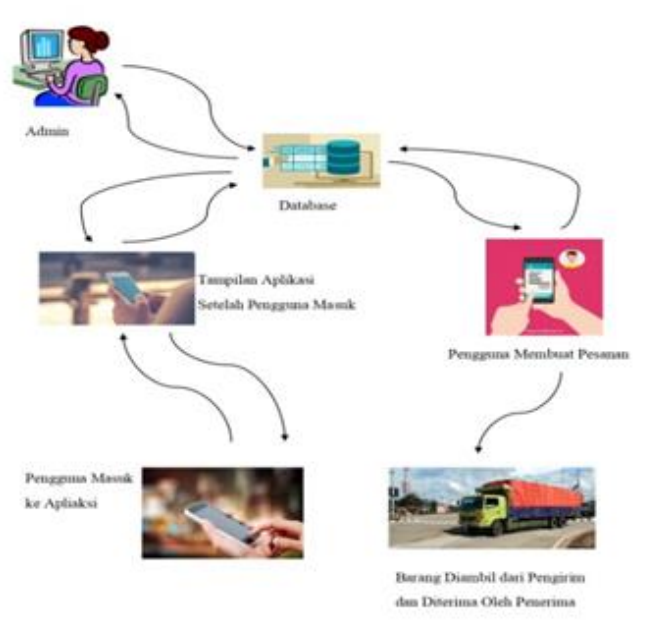

Gambar 2. Gambaran Umum Sistem

Dari gambaran umum sistem diatas user menggunakan android untuk login ke aplikasi. User yang belum memiliki akun untuk masuk, dapat membuat akun terlebih dahulu dengan menggunakan email dan kata kunci (password). Setelah pengguna berhasil login ke apliaksi, akan muncul tampilan beberapa menu dari aplikasi seperti, Home, Call Center, Booking, dan History Pesanan. Jika pengguna ingin langsung memesan (booking) pengangkutan, maka dapat memilih menu booking, kemudian mengisi data-data, jenis barang, berat barang, nama pengirim, nama penerima, lokasi pengambilan barang dan pengantaran barang, dan akan terhubung dengan database. Setelah data selesai diisi, maka pesanan akan diproses, admin akan melakukan cross check dan langsung menghubungi pengguna untuk konfirmasi mengenai harga dan konfirmasi ulang data yang sudah diisi oleh pengguna.

\subsection{Usecase Diagram}

Usecase diagram bertujuan untuk menggambarkan apa yang dilakukan sistem dan siapa yang beriteraksi dengan sistem, terlihat pada gambar 2.4 berikut:

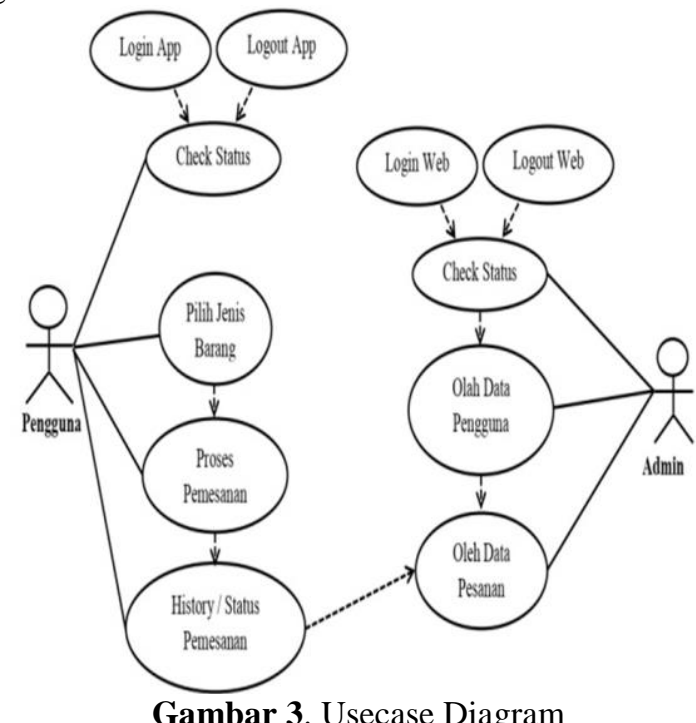

Gambar 3. Usecase Diagram 


\subsection{Activity Diagram}

Berikut ini merupakan activity diagram dari

Perancangan Aplikasi Pengantaran Barang (Ekspedisi) Antar Sumatera Berbasis Android.

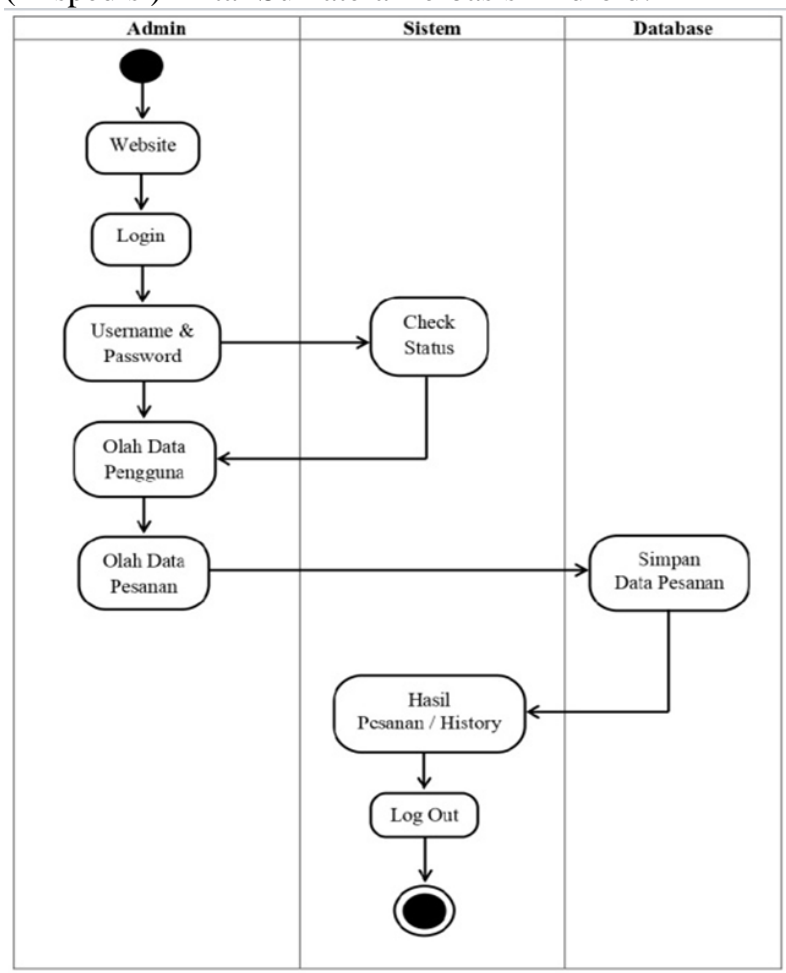

Gambar 4. Activity Diagram

\subsection{Tampilan Aplikasi}

Hasil Perancangan Aplikasi Pengantaran Barang (Ekspedisi) Antar Sumatera Berbasis Android dapat digunakan pada sistem operasi Android minimal versi 4.1 (Jelly Bean). Berikut merupakan tampilan implementasi aplikasi:

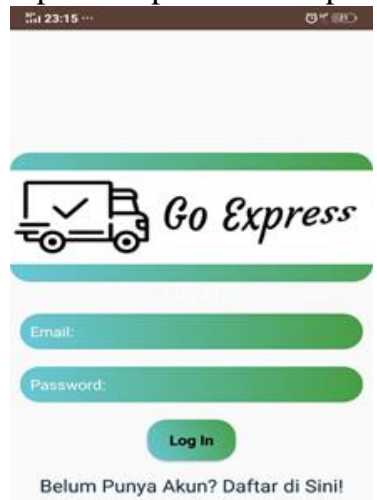

Gambar 5: Halaman Login Pengguna

Tampilan diatas merupakan tampilan login user untuk menggunakan aplikasi dalam pemesanan jasa pengangkutan. Pada saat login, jika pengguna belum memiliki akun atau belum pernah mendaftar, pengguna harus membuat akun terlebih dahulu. Data yang diperlukan untuk membuat akun yaitu nama,

jenis kelamin, nomor telepon, alamat surel, dan kata sandi

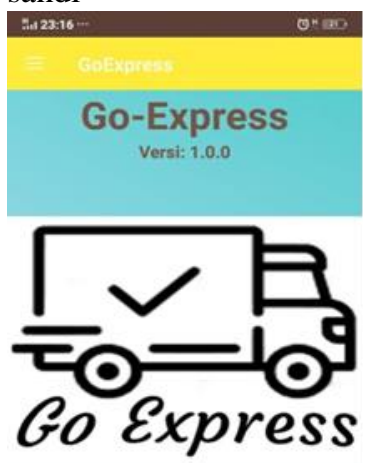

Aplikasi digunakan untuk memudahkan pengguna dalam jasa pengangkutan, penjemputan dan pengangkutan, penjemputan
pengantaran barang. pengantaran barang.
Pemesanan truk hanya
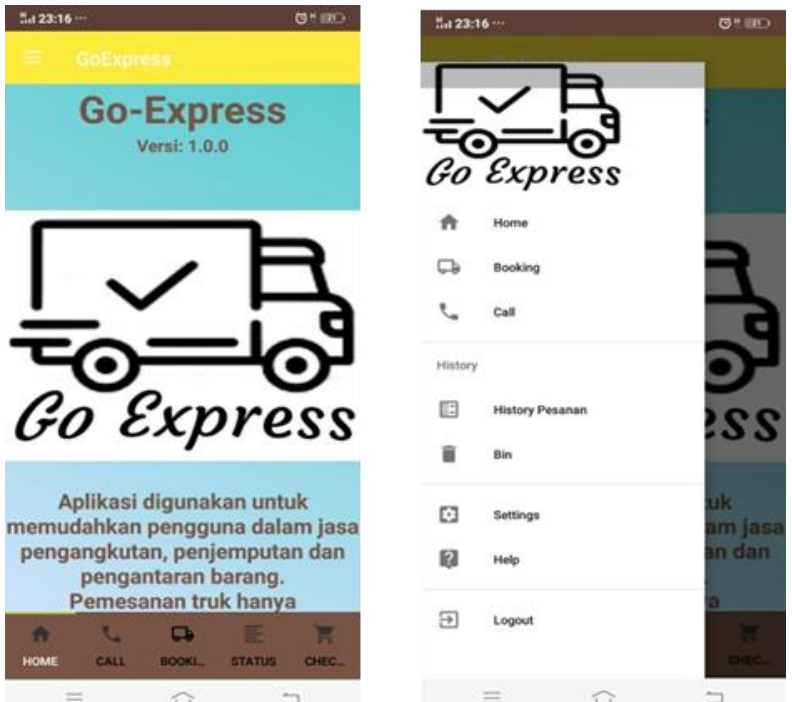

Gambar 6. Halaman Utama Aplikasi

Gambar diatas merupakan halaman utama aplikasi. Telah tersedia beberapa menu yang dapat dipilih oleh pengguna. Mulai dari call center sampai pada history.
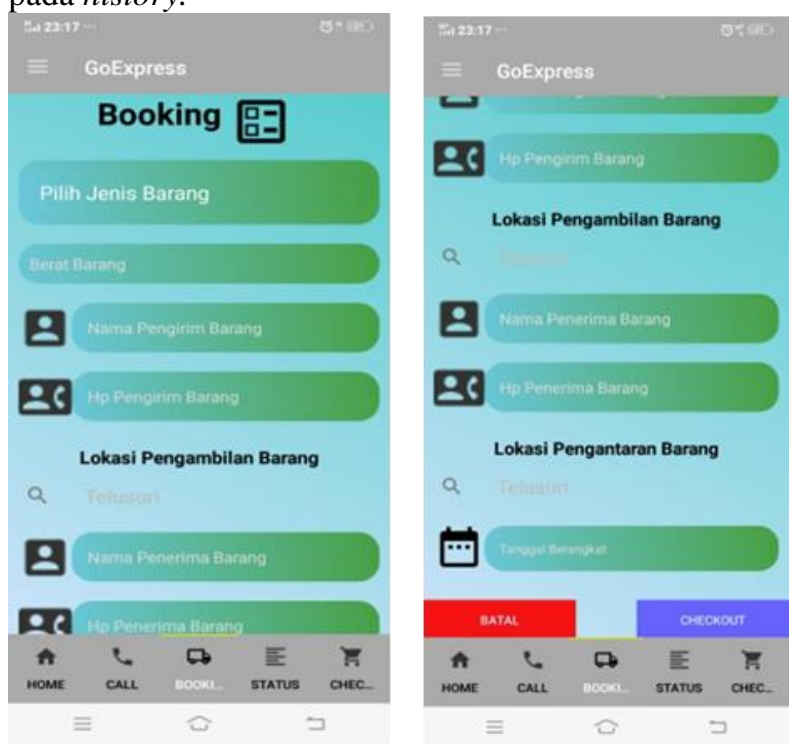

Gambar 7. Menu Booking Truk

Gambar diatas merupakan pengisian menu booking. Pengguna mengisi jenis barang yang akan dikirim, berat barang, nama pengirim, nomor telepeon, alamat pengambilan barang, nama penerima barang, nomor telepon penerima barang, alamat penerima barang dan tanggal berangkat. Setelah semua diisi lengkap, maka pengguna klik checkout, setelah klik checkout akan muncul tampilan seperti gambar dibawah 

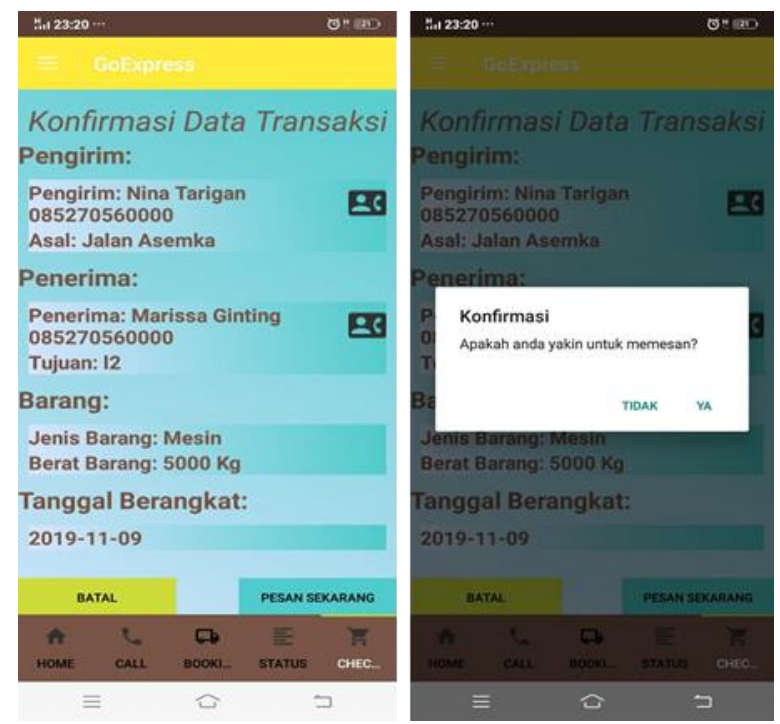

Gambar 8. Konfirmasi Pemesanan Truk

Gambar diatas merupakan notifikasi untuk pemesanan barang. Setelah pengguna klik pesan sekarang, maka akan muncul peringatan seperti gambar diatas. Jika pengguna klik tidak, maka akan kembali ke menu sebelumnya. Jika pengguna klik ya, aplikasi pengguna akan langsung terhubung dengan database, dan admin akan segera menghubungi pengguna dan akan muncul tampilan seperti gambar dibawah.

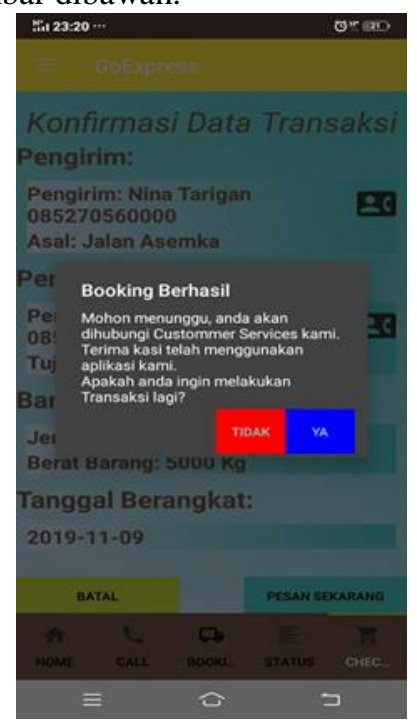

Gambar 9. Konfirmasi Pemesanan Truk

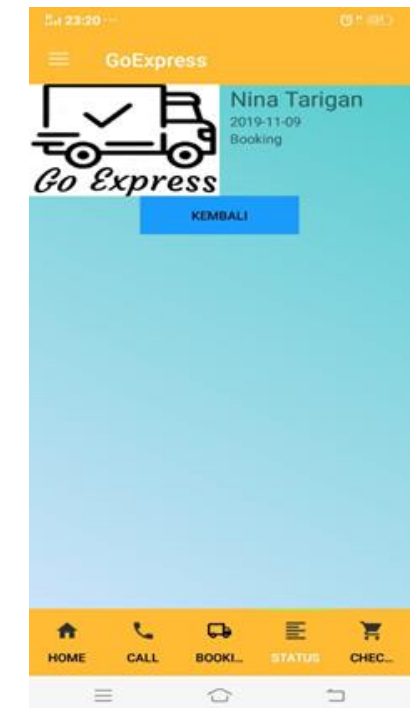

Gambar 10. Tampilan Status Pesanan

Gambar diatas merupakan tampilan menu status. Jika pengguna sudah melakukan pesanan dan admin sudah menyetujui pesanan, maka data akan langsung diproses di web server oleh admin. Ketika pesanan masih dalam status booking, artinya barang masih disiapkan, status packing artinya barang sedang dimuat/dimasukkan kedalam truk, delivery artinya barang sedang dalam perjalanan, dan selesai artinya barang sudah selesai diantar dan sudah diterima.

\section{KESIMPULAN}

Berdasarkan hasil penelitian telah dilaksanakan, peneliti dapat menyimpulkan beberapa hal, antara lain :

a) Aplikasi jasa pengiriman barang dapat menerima permintaan armada pengiriman barang lebih dari satu pelanggan dalam waktu yang bersamaan.

b) Data pemesanan armada pengiriman barang dapat terdata dengan baik dan lengkap.

c) Pelanggan dapat dengan mudah mengakses informasi pengiriman barang dimana saja, kapan saja dan dari mana saja, serta penyebaran informasi pengiriman barang yang lebih lengkap dan akurat.

d) Pelanggan dapat mengetahui secara langsung total biaya pengiriman barang yang dilakukannya tanpa harus melalui pihak ketiga.

e) Proses klaim barang dapat terselesaikan dengan baik, dengan adanya aturan baku yang mengatur proses klaim barang serta bukti yang harus dilampir oleh pelanggan ketika klaim barang. Sehingga tidak ada lagi pihak yang Saran merasa dirugikan dengan adanya klaim barang.

Pada penelitian ini belum ada pemmbahasan tentang berapa user yang dapat dilayani per detiknya. Dan juga belum membahas tentang tingkat keamanan data dan aplikasi. Jika dikemudian hari peneliti selanjutnya melakukan penelitian atau 
melanjutkan penelitian ini, penulis berharap peneliti selanjutnya dapat mengembangkan sistem dan aplikasi ini untuk menjadi lebih baik lagi.

\section{DAFTAR PUSTAKA}

[1] Ibnu Reza El Islamy, Denzy, Riko Marsela, Rio Filanno, Delima Sitanggang, Hendra Pasaribu and Mardi Turnip, Package Placement Application Based on Location Tracking on Android Platform MECNIT 2018, IOP Conf. Series: Journal of Physics: Conf. Series 1230 (2019) 012079IOP Publishingdoi:10.1088/17426596/1230/1/012079

[2] Hidayat, Rachmat. 2014. Sistem Informasi Ekspedisi Barang Dengan Metode E- CRM Untuk Meningkatkan Pelayanan Pelanggan. ISSN: 2088 -17622. Jakarta: Jurnal Sisfotek Global Vol. 4, No. 2, September 2014.

[3] Kristanto, Andri. 2008. Perancangan Sistem Informasi dan Aplikasinya. Yogyakarta: Gaya Media.

[4] Lestari, Ika Wahyu Puji. 2014. Sistem Informasi Pemaketan Barang Pada Alfath Tours Dan Travel Pacitan. ISSN: 2302 - 5700.

Surabaya: Indonesian Journal on Networking and Security Vol. 3, No. 4, Oktober 2014:13-17.

[5] Mulyanto, Agus. 2009. Sistem Informasi Konsep dan Aplikasi. Yogyakarta: Pustaka Pelajar

[6] Nugroho,Singgih Wahyu, Andri Suprayogi dan Haniah. 2015. Pengembangan Aplikasi Sebaran Peta Kantor Pelayanan Jasa Ekspedisi TIKI Berbasis Mobile GIS Pada Smartphone Android. ISSN: 2337 - 845X. Semarang: Jurnal Geodesi Undip Vol. 4, No. 1, Januari 2015:141-149.

[7] E. Indra, Steffanily, and T. Dinesh, "Designing Android Gaming News \& Information Application Using Java-Based Web Scraping Technique," J. Phys. Conf. Ser., vol. 1230, p. 012069, Jul. 2019, doi: 10.1088/1742$6596 / 1230 / 1 / 012069$. 